\title{
DANSYLPROTAMINE, A FLUOROMETRIC REAGENT FOR DETERMINATION OF NUCLEIC ACIDS
}

\author{
Noriko NAKAMURA, Toshio KINOSHITA ${ }^{\circledR *}$; Kazuyo MURAYAMA*, \\ and Fumio IINUMA**
}

\begin{abstract}
Kanagawa Prefectural College of Medical Technolagy, Nakao-cho, Asahi-ku, Yokohama 241, *School of Pharmaceutical Sciences, Kitasato University, Shirokane, Minato-ku, Tokyo 108, and **Faculty of Pharmaceutical Sciences, Teikyo University, Sagamiko, Kanagawa 199-01
\end{abstract}

DNA and RNA were found to enhance the fluorescence of dansylprotamine. This finding was applied to microdetermination of nucleic acids. This method is valid for samples containing $0.1-5.0 \mu \mathrm{g} / \mathrm{ml}$ of nucleic acids. Nucleic acids and dansylprotamine were found to bind each other through both electrostatic and hydrophobic interaction.

Nucleic acids have currently been determined using 3,5-diaminobenzoic acid ${ }^{1)}$ or ethidium bromide ${ }^{2) 3)}$. However, the former reagent requires heating for a long period in the presence of strong acid, and the latter reagent gives excitation and emission maxima at too close wavelengths (546 and $590 \mathrm{~nm}$ ). Moreover, ethidium bromide has been found to be highly carcinogenic. Recently, new reagents for the fluorescent staining of DNA, 4',6'-diamino-2-phenylindole ${ }^{4) 5)}$ and 2-[2-(4-hydroxyphenyl)-6-benzimidazole]-6(1-methy-4-piperazyl)-benzimidazole trihydrochloride ${ }^{6) 7)}$ were reported but these compounds do not stain RNA. In the present study, DNA and RNA were found to enhance the fluorescence of dansylprotamine (DNSP) whose fluorescence is quenched in aqueous media, and this finding was applied to the determination of DNA and RNA.

\section{MATERIALS AND METHODS}

Dansylchloride (DNS-Cl) and 8-anilinonaphthalene-1-sulfonate (ANS) were purchased from Tokyo Chemical Industry Co., Ltd. (Tokyo). Cycloheptaamylose (C7A) was obtained from Hayashibara Biochemical Laboratories, Inc. (Tokyo), and once recrystallized from water before use. Protamine and DNA from salmon testis were the gift of Dr. M. Wakaomi, Yuki Gosei Yakuhin Kogyo Co. Ltd. (Tokyo). RNA from yeast was obtained from Wako Pure Chemical Industries, Ltd. (Tokyo). A Hitachi Model 204-R fluorescence spectrophotometer was used for the fluorometric measurements, and a Hitachi Model 200-10 spectrophotometer was used for measuring absorbances.

Preparation of DNSP - Protamine was dansylated with cycloheptaamylose-dansylchloride complex $(\mathrm{CDC})^{8) 9)}$ in the manner described previously ${ }^{10}$ ) with some modifications. To $10 \mathrm{ml}$ of $16 \%$ C7A solution in aqueous $8 \mathrm{M}$ guanidine hydrochloride was added $100 \mathrm{mg}$ of protamine, $250 \mathrm{mg}$ of CDC and $1 \mathrm{ml}$ of $40 \%$ triethanolamine in isopropanol. The resulting mixture was magnetically stirred for $10 \mathrm{~min}$ at $37^{\circ} \mathrm{C}$. The mixture was then applied on a Sephadex column $(2 \mathrm{~cm} \times 20 \mathrm{~cm})$ and DNSP was eluted from the column 
with $0.1 \mathrm{M}$ acetate buffer containing $1 \mathrm{M} \mathrm{KCl}, \mathrm{pH}$ 4.0. The effluent was dialysed overnight against 0.1 $\mathrm{M}$ phosphate buffer, $\mathrm{pH}$ 7.4. Concentration of DNSP in the dialysed solution was determined by measuring its absorbance of DNS group at $335 \mathrm{~nm}^{10}$ ) and the solution was properly diluted to give the DNSP reagent.

Determination of nucleic acids - To $50 \mu \mathrm{l}$ of a sample solution was added $3 \mathrm{ml}$ of DNSP reagent (6 $\mu \mathrm{M}$ DNSP in $25 \mathrm{mM}$ phosphate buffer, $\mathrm{pH} 7.0$ ) at room temperature and the fluorescence intensity was measured at excitation and emission wavelengths of 360 and $515 \mathrm{~nm}$.

Fluorescence enhancement of ANS with DNA-protamine complex - - To $2 \mathrm{ml}$ of $11.7 \mu \mathrm{M}$ ANS solution in glycine buffer was added $1 \mathrm{ml}$ of an aqueous solution containing $50 \mu \mathrm{g}$ protamine and $20 \mu \mathrm{g}$ DNA. The fluorescence intensity was measured at excitation and emission wavelengths of 395 and 500 $\mathrm{nm}$.

\section{RESULTS AND DISCUSSION}

Figure 1 shows the excitation and fluorescence spectra of the mixture of DNA and DNSP and that of DNSP alone. Although the fluorescence intensity of DNSP in aqueous media was low, it was markedly enhanced on addition of DNA. The increment of fluorescence was proportional to the concentration of DNA. Nucleic acids showed no significant fluorescence within the concentration range used for the deter mination.

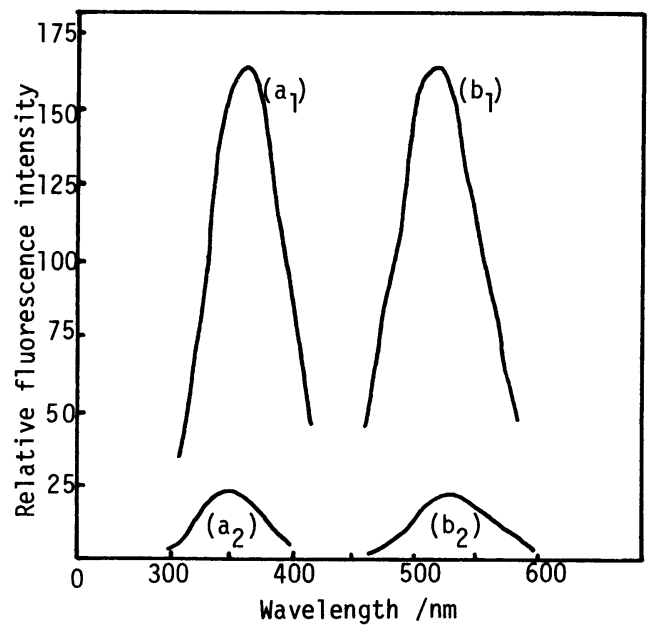

Fig.1 (a) Excitation and (b) emission spectra of the mixture of $50 \mu \mathrm{l}$ of aqueous 0.02 $\mathrm{w} / \mathrm{v} \%$ DNA solution and $3 \mathrm{ml}$ of DNSP reagent $\left(a_{1}, b_{1}\right)$ and reagent blank $\left(a_{2}\right.$, $b_{2}$ ).

Figure 2 displays the fluorescence intensity of DNA-DNSP mixture plotted against the concentration of DNSP. The fluorescence intensity showed a plateau at the concentration of DNSP between 1 and 7.5 $\mu \mathrm{M}$, whereas the reagent blank increased with increasing concentration of DNSP. The effect of $\mathrm{pH}$ was examined by measuring the fluorescence in the presence of DNA at different pH values in $25 \mathrm{mM}$ phosphate buffer. The fluorescence intensity showed its maximum in the $\mathrm{pH}$ range between 6.4 and 8.0. Accordingly, $6 \mu \mathrm{M}$ DNSP in $25 \mathrm{mM}$ phosphate buffer, $\mathrm{pH} 7.0$, was used in the standard procedure. Linear 
relations were found between increment of fluorescence intensity and the concentration of DNA and RNA in the range of final concentration from 0.1 to $5.0 \mu \mathrm{g} / \mathrm{ml}$ as demonstrated in Fig. 3.

Table 1 lists the effect of several compounds on the fluorescence intensity of DNA-DNSP mixture. The fluorescence was not affected by glucose, leucine, benzoate and Tween 20. Although $10 \mu \mathrm{g} / \mathrm{sample}$ of bovine serum albumin (BSA) did not affect the fluorescence, $100 \mu \mathrm{g} / \mathrm{sample}$ of $\mathrm{BSA}$ increased the fluorescence of $10 \mu \mathrm{g} / \mathrm{sample}$ of DNA by $9 \%$. Mucopolysaccharides tested (chondroitin sulfate $\mathrm{A}, \mathrm{C}$, and heparin) greatly affected the fluorescence. Therefore, these compounds should be removed prior to the determination.

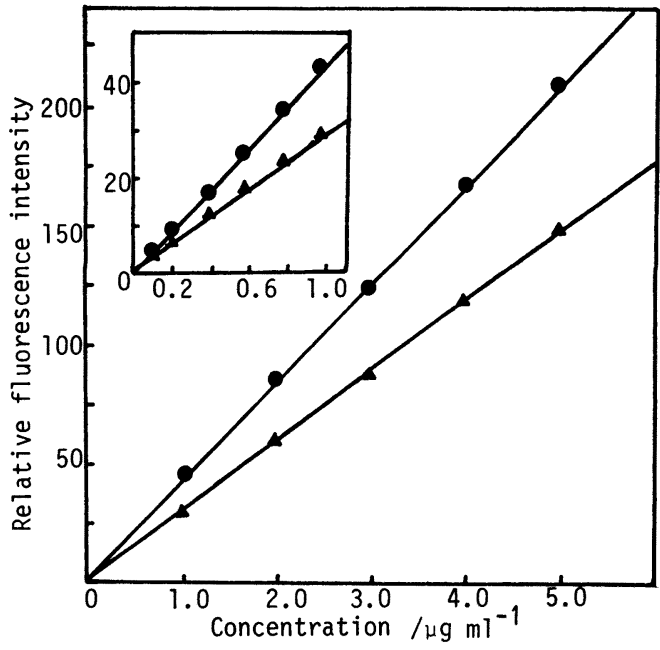

Fig. 3 Standard curves for DNA $(\boldsymbol{)})$ and RNA (A).

Table 1 Relative fluorescence intensity of DNA (10 $\mu \mathrm{g} / \mathrm{sample}$ )-DNSP complex in the presence of several compounds.

To $50 \mu \mathrm{l}$ of aqueous $0.02 \mathrm{w} / \mathrm{v} \%$ DNA solution were added $1 \mathrm{ml}$ of $18 \mathrm{nmol}$ DNSP in $25 \mathrm{mM}$ phosphate buffer, $\mathrm{pH} 7.0$ and $2 \mathrm{ml}$ of various compounds dissolved in $25 \mathrm{mM}$ phosphate buffer, pH 7.0. Fluorescence intensity was measured at ex. $360 \mathrm{~nm}$ and em. $515 \mathrm{~nm}$.

\begin{tabular}{|c|c|c|c|c|c|}
\hline Compounds & $\begin{array}{l}\text { Amount } \\
\text { ( } \mu \mathrm{g} / \mathrm{sample})\end{array}$ & $\begin{array}{l}\text { Recovery } \\
\text { (\%) }\end{array}$ & Compounds & $\begin{array}{l}\text { Amount } \\
\text { ( } \mu \mathrm{g} / \text { sample) }\end{array}$ & $\begin{array}{c}\text { Recovery } \\
\text { (\%) }\end{array}$ \\
\hline none & - & 100 & & & \\
\hline \multirow[t]{2}{*}{ glucose } & 10 & 100 & bovine serum albumin & 10 & 100 \\
\hline & 100 & 100 & & 100 & 109 \\
\hline \multirow[t]{2}{*}{ sodium benzoate } & 10 & 100 & chondroitin sulfate $A$ & 10 & 135 \\
\hline & 100 & 100 & & 100 & 357 \\
\hline \multirow[t]{2}{*}{ Tween 20} & 10 & 100 & chondroitin sulfate $C$ & 10 & 130 \\
\hline & 100 & 100 & & 100 & 328 \\
\hline \multirow[t]{2}{*}{ L-leucine } & 10 & 100 & heparin & 10 & 242 \\
\hline & 100 & 100 & & 100 & 742 \\
\hline
\end{tabular}

This method is very simple because stable fluorescence is obtained by only mixing DNSP solution with samples at room temperature. Furthermore, DNSP itself is stable at least for two months when stored in a refrigerator. DNSP method utilizes the fluorescence enhancement of DNSP on its interaction with nucleic acids and therefore is superior to the methods utilizing fluorescence quenching of dyes such as acridine orange.

DNSP is a fluorescence reagent having polyfunctional binding sites (polyarginine moiety) which bind tightly with nucleic acids. Several factors which may affect the binding were investigated. First, the 
effect of ionic strength on the fluorescence intensity was examined using various concentration of $\mathrm{KCl}$ solution and the results are displayed in Fig. 4. The fluorescence decreased with the increasing concentration of $\mathrm{KCl}$. The fluorescence continued to decrease up to the ionic strength of $\mu=0.5$. The $100 \mathrm{mM}$ phosphate buffer used in the determination did not affect the fluorescence. On the other hand, addition of urea reduced the fluorescence intensity as shown in Fig. 5. These facts suggest that both electrostatic and hydrophobic interactions between nucleic acids and DNS-group are involved in the enhancement of the fluorescence.

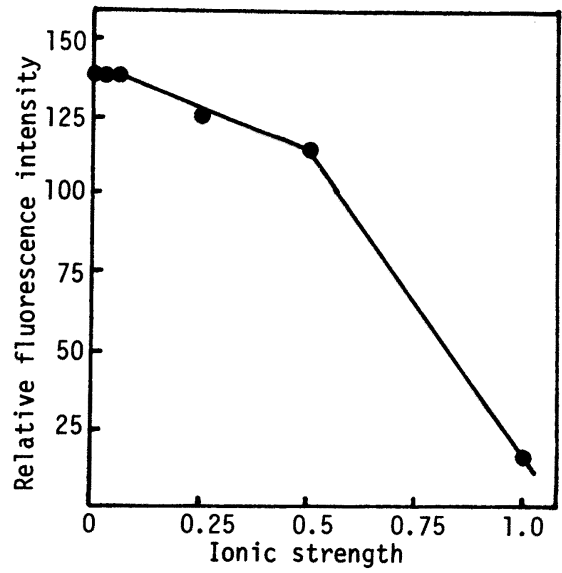

Fig. 4 Relative fluorescence intensity of DNA-DNSP complex under various ionic strength.

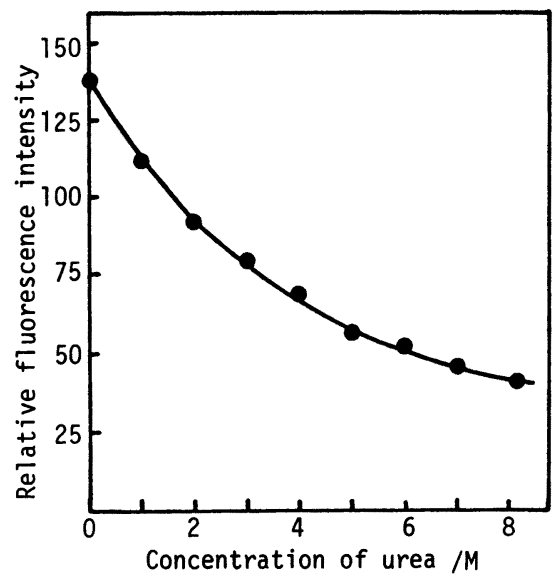

Fig. 5 Relative fluorescence intensity of DNA-DNSP complex in the presence of various concentration of urea.

To $50 \mu \mathrm{l}$ of aqueous $0.02 \mathrm{w} / \mathrm{v} \%$ DNA solution were added $1 \mathrm{ml}$ of $18 \mathrm{nmol}$ DNSP in $25 \mathrm{mM}$ phosphate buffer, $\mathrm{pH} 7.0$ and $2 \mathrm{ml}$ of various concentration of $\mathrm{KCl}$ or urea solution in $25 \mathrm{mM}$ phosphate buffer, $\mathrm{pH} 7.0$. Fluorescence intensity was measured at ex. $360 \mathrm{~nm}$ and em. $515 \mathrm{~nm}$.

Fig. 6 Fluorescence spectra of $1.17 \times 10^{-5} \mathrm{M}$ ANS in the presence of protamine and DNA (final volume: $3 \mathrm{ml}$ ).

$$
\begin{aligned}
& \text { ANS }+50 \mu \mathrm{g} \text { protamine } \\
& +20 \mu \mathrm{g} \text { DNA }
\end{aligned}
$$

-.-.- ANS + $50 \mu \mathrm{\mu g}$ protamine .......... ANS alone

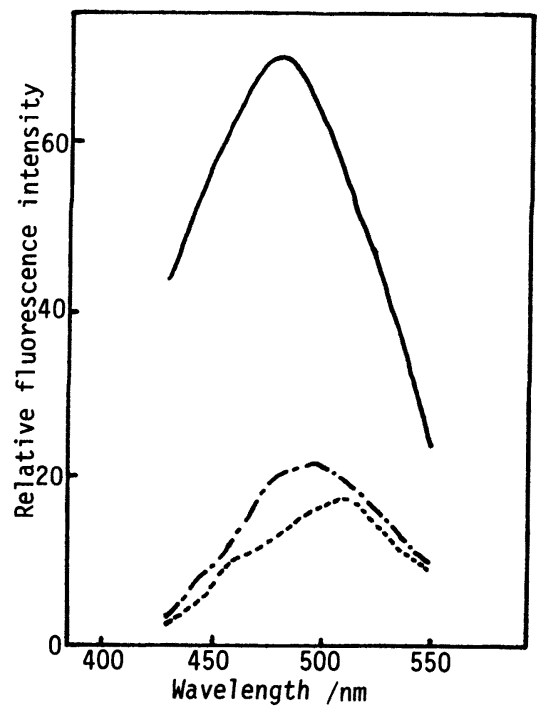


The induction of hydrophobic region on the interaction between protamine and DNA was further explored using ANS, which is an effective hydrophobic probe for proteins. ANS fluoresced very little in the presence of either intact (not dansylated) protamine or DNA alone, but its fluorescence was markedly enhanced on simultaneous addition of both protamine and DNA.

Figure 6 demonstrates the fluorescence intensity of ANS in the presence and absence of DNA-protamine complex. It has already been reported that protamine forms the random coil in aqueous solution but it is converted rapidly into the $\alpha$-helix form on interaction with DNA and it $t$ wins itself round the cruck of double helical DNA ${ }^{11)}$. The enhancement of fluorescence intensity of ANS in the presence of DNA-protamine complex indicates the induction of hydrophobic regions by the interaction between protamine and DNA presumably due to the increase of the $\alpha$-helix form. The interaction of DNSP and nucleic acids may also result in the induction of hydrophobic regions which may contribute to the enhancement of the fluorescence intensity of the dansyl group. Kinoshita and linuma ${ }^{10)}$ have previously reported that heparin enhances the fluorescence of DNSP to a great extent. As heparin possesses little hydrophobic group in its molecule, this fact further supports the assumption that the fluorescence enhancement of DNSP is caused mainly by the induction of hydrophobic region in the protamine molecule.

\section{Acknowledgements}

The authors are grateful to Dr. M. Wakaomi, Yuki Gosei Yakuhin Kogyo Co. Ltd., for his generous gift of specimens of protamine and DNA.

\section{REFERENCES}

1) J. M. Kissane, E. Robins : J. Biol. Chem., 233, 184 (1958).

2) J. B. LePecq, P. Yot, C. Paoletti : Compt. Rend., 259, 1786 (1964).

3) A. S. Prasad, E. DuMocuhelle, D. Koniuch, D. Oberleas : J. Lab. Clin. Med., 80, 598 (1972).

4) W. C. Russel, C. Newman, D. H. Williamson : Nature(London), 253, 461 (1975).

5) J. Kapuscinski, B. Skoczylas : Anal. Biochem., 83, 252 (1977).

6) C. F. Cesarone, C. Bolgnesi, L. Santi : Anal. Biochem., 100, 188 (1979).

7) C. Labarca, K. Paigen : Anal. Biochem., 102, 344 (1980).

8) T. Kinoshita, F. Iinuma, A. Tsuji : Chem. Pharm. Bull., $\underline{22}, 2421$ (1974).

9) T. Kinoshita, F. linuma, A. Tsuji : Anal. Biochem., 61, 632 (1974).

10) T. Kinoshita, F. Iinuma, A. Tsuji : Chem. Pharm. Bull., 22, 2769 (1974).

11) R. W. Warrant, S. H. Kim : Nature, 271, 130 (1978).

\section{Keyword phrases}

nucleic acid determination ; fluorometry of nucleic acid ; DNA fluorometry; RNA fluorometry; dansyl protamine as fluorescence reagent; protamine interaction with nucleic acid. 